\title{
Negotiating legitimacy: Media publics and security policy in multi-ethnic Britain ${ }^{1}$
}

\author{
Marie Gillespie $^{2}$
}

\begin{abstract}
The article examines how multi-ethnic publics debate questions of legitimacy. It explains the deep public scepticism surrounding the Iraq War (2003) and subsequent security policy, not just in terms of declining trust in the PM Tony Blair, but as a corrosive "legitimacy deficit" with significant implications for the prospects of participatory democracy and multicultural citizenship. The arguments are grounded in a collaborative ethnography of news audiences across the UK, including multilingual and multi-ethnic audiences. Using a Weberian framework, the article analyses the patterning of interviewees' responses to the justifications given for going to war, and it assesses the implications of the "legitimacy deficit" for the UK and its international security policy.
\end{abstract}

Key words: Iraq war; legitimacy deficit; news audiences; ethnography.

Resumo: Este artigo examina como públicos de origem multi-étnica debatem questões de legitimidade. Ele explica o profundo ceticismo envolvendo a guerra do Iraque (2003) e a subseqüente política de segurança, não somente em termos da diminuição na confiança no Primeiro Ministro Tony Blair, mas também do corrosivo "déficit de legitimidade" que trouxe implicações significativas para o futuro da democracia participativa e da cidadania multicultural. Os argumentos foram baseados em uma etnografia colaborativa de audiências de programas jornalísticos espalhadas pelo Reino Unido, incluindo audiências de diversas línguas e etnias. Usando um quadro de referência Weberiano, o artigo analisa o padrão das respostas dos entrevistados com relação às justificativas dadas para a guerra, e avalia as implicações do "déficit de legitimidade' para a política de segurança internacional do Reino Unido.

Palavras-chave: Guerra do Iraque; déficit de legitimidade; audiências de programas jornalísticos; etnografia.

\footnotetext{
${ }^{1}$ Este artigo é baseado em uma pesquisa financiada pelo ESRC como parte do seu programa de pesquisa New Challenges to Security (Award Ref RES-223-25-0063). Os detalhes completos do projeto podem ser encontrados na página www.mediatingsecurity.com. Este artigo é uma discussão preliminar do material das entrevistas, uma parte do qual, foi coletado por mim em Swansea. Uma boa parte dos dados ainda necessita de análise. Eu sou agradecida ao Dr. Ben O' Loughlin (KCL), que me ajudou na preparação deste artigo, e ao Dr. Tom Cheesman (Swansea). As eventuais falhas devem ser totalmente debitadas à minha pessoa. Este artigo foi originalmente publicado na revista International Relations, vol.20, n. 4, 2006.

${ }^{2}$ Marie Gillespie é PhD, e professora da Open University. Ela já publicou diversos livros, entre eles: Security, Media and Legitimacy in Multi-ethnic Britain (2007); After September 11: Television News and Transnational Audiences (2006); Media Audiences (2005).
} 


\section{Introduction}

The failure of the British government to persuade large sections of the public that military action in Iraq in 2003 was necessary, moral, legal, logical, or just, was apparent when up to a million people joined the anti-war demonstration in London on $15^{\text {th }}$ February, 2003 (http://news.bbc.co.uk/1/hi/uk/2767761.stm and for global protest, http://news.bbc.co.uk/1/hi/world/europe/2765215.stm) . Such protests did not, however, redirect the policy of President George W. Bush and Prime Minister Tony Blair from preemptive military action. Subsequent events have done little to assuage a widespread sense of public unease: the worsening security situation in Iraq, the seemingly greater threat of terrorism, and the erosion of civil liberties at home, have fed growing scepticism among large sections of the public. The information upon which the public makes political judgements comes mainly via the news media. But the news media, like politicians, are increasingly regarded with scepticism. The adversarial relations between politicians and the media (as in the Andrew Gilligan / David Kelly affair) only tend to diminish, rather than strengthen, the credibility of both.

Security policy, according to much mainstream news media coverage, as well as numerous public opinion polls, is out of step with public sentiment. ${ }^{3}$ But neither news media nor public opinions polls, useful as they may be in representing protest or tracking trends, are able to analyse processes of democratic deliberation: how public perceptions and judgements are arrived at, and the modes of reasoning and affective engagements which people bring to their appraisal of security policy, in large part via their uses of news media. Audience ethnography can assist us in this task. It is a form of research which analyses how interpretations and uses of media connect with the wider social and political contexts of people's lives. It is a culturally sensitive methodology based on in depth interviews, participant and non participant observation in the lives of research subjects. It depends on a sociological knowledge of people's lives and backgrounds (unlike focus groups). Audience ethnography can deliver rich insights into cultural

3 Opinion poll data showing declining support for the Iraq war since 2003: http://www.icmresearch.co.uk/reviews/2003/guardian-bombingiraq18-april-2003.htm $\quad$ and http://www.icmresearch.co.uk/reviews/vote-intention-reports/bombing-iraq.asp. 
Revista da Associação Nacional dos

Programas de Pós-Graduação em Comunicação

\section{(e) compós}

www.compos.org.br

identities and differences as they shape, and are shaped by, media consumption. It can further understanding of socio-cultural and political processes of deliberative democracy: into the logics, patterns and forms of discourse used by the public in making political judgements - processes that are often neglected in studies of international relations (Gillespie, 2005). In this article I hope to contribute to studies of international relations by drawing on ethnographic data to shed light on public responses to the stated reasons for the invasion of Iraq war and the justification of subsequent security policy in terms of the War on Terror (WoT).

The ethnographic data was gathered as part of a collaborative, interdisciplinary research project which set out to examine the changing relationship between government, media and culturally diverse publics in the UK following the Iraq war 2003. The research analyses attributions of salience, credibility and legitimacy to the actions and rhetoric of different media and political actors and agencies - and the trade offs between these values. It assesses the implications of security policy and its mediation for the prospects for participatory democracy and multicultural citizenship.

Between September 2004 and April 2006 in-depth interviews, lasting up to two hours, were carried out by 10 researchers with 173 people across the UK: in Edinburgh, Belfast, Dublin, Swansea, Bradford, Keighley, Oldham, the East End of London, and Surrey. Each interview was recorded and transcribed. The interview data was then input into a qualitative data analysis software programme (NVivo 2). The data was coded and categorised making it possible to question and search the data systematically and facilitate analysis.

The age of interviewees ranged from 11 to 82 with the bulk in the 20-35 year age range. 81 were women and 92 men. Our interviewees were drawn from different faith communities. 90 described themselves as Muslim, 20 as Hindu, 13 as Catholic, and 6 as Protestant. Others described themselves atheist, agnostic, secular or "of no faith”. The majority of our interviewees spoke English as a second language and one or more of the following languages: Sylheti, Bengali, Urdu, Punjabi, Hindi, Arabic, Swaheli.

The research grew out of a previous collaborative ethnography on television news and transnational audiences after September 112001 (Gillespie, 2006). As with this 
previous study, we set out to document a range of political perspectives and views held by British citizens, including those of British Muslims. But we wished to avoid an exclusive focus on Muslims as the feeling of being under constant and intense public and media scrutiny, especially since 9/11 2001, has contributed to a growing sense of social unease and marginalisation. We were interested in comparing and contrasting minority and majority ethnic groups - the assumption being that having an ethnic identity is not exclusive to groups identifiable or categorised by dubious markers of 'race'. Everyone has an ethnicity and it is a relational not a fixed category or attribute: ethnic identities are defined and constantly re-defined in relation to perceived 'others' and events. We were also aware that the term 'Muslim', through referring to a religious category and group, is often used to refer to a 'race'. To further confuse matters, British South Asians and Arabs often find themselves categorised as Muslims by virtue of perceived shared racial attributes. Such processes of racialisation and encompassment have become more apparent in the aftermath of September 112001.

We were also keen to include people from a wide range of socio-economic backgrounds, especially given that levels of cultural and educational capital are important indicators of media and political literacy. Interviews were conducted every six weeks around key security themes and events (7/7 the cartoon controversy) and all researchers were given an open-ended interview schedule to follow, albeit with flexibility, to facilitate comparative analysis of people in particular places(for further details see www.mediatingsecurity.com). Repeat interviews tracked shifting perspectives on security policy across time. Our interviewee subjects were conceived of as both news audiences and as publics.

\section{News Audiences and Publics}

News audiences are not identical with publics but they do overlap. They have different orientations (entertainment or distraction for an audience; information and education for a public), and they have different disciplinary homes (sociology versus politics). They are equally slippery concepts, and hard to pin down empirically as media technologies, texts and contexts of reception multiply, and patterns of media use diversify 
Revista da Associação Nacional dos

Programas de Pós-Graduação em Comunicação

\section{(e) compós}

www.compos.org.br

(think of all the ways and places you can now receive news). News audiences are increasingly hard to define and study, while the concept of a public can connote anything from a shared understanding of the world, a common identity, or a claim to inclusiveness, to a consensus about collective interests (Livingstone, 2005). But "Shifting Securities" project, upon whose results this analysis draws, attempts to research audiences as publics: that is, to examine whether and how uses of media, and responses to political discourse via the media,enable or impede political participation, democratic debate and multicultural citizenship.

News cultures and political cultures are mutually constitutive: they interact in symbiotic fashion. It is very rarely possible to disentangle "effects" of news media from prior convictions. Through using news media, people may experience membership of a public or of multiple (national and transnational) publics, if only temporarily. But they may not. Audiences are not always part of a public, for reasons which include censorship, lack of cultural or educational capital or personal preference.

As members of news audiences and publics we have to grapple with fundamental contradictions at the heart of contemporary culture. We are more interconnected (transnational communities of language, religion or interest), but also more disconnected (through market fragmentation). Media are more homogeneous (global media corporations) but also more heterogeneous: we may select media that support tendencies towards democratization, or those that support regressive nationalisms, regionalisms and fundamentalisms. In many ways, media have fundamentally altered the conduct and nature of politics and of political debate at times opening up and democratising spaces of communication at the same time as closing down alternative discursive possibilities (see for example, Hoskins in this volume and Rajagopal, 2001). Our project delivers insights into the intersections of global and local, national and international relations as they bear upon the everyday lives and identities of UK citizens as new audiences and - sometimes - publics.

The increasing array of transnational media, and growing uses of the internet, makes it much harder for governments to get their policy messages across and so to secure legitimacy (see Gillespie, 2006). Conversely it is getting much easier for news 
audiences to forge "micro public spheres", in which one hears and sees only what conforms to, and confirms, a pre-existing world view: ritualistic uses of media are mobilised in the 'ontological security' management strategies of audiences. This can lead to insular, rigid forms of thinking that augment a sense of certainty and security (Aksoy, 2006). But we find also that many minority ethnic UK citizens, especially those who possess multilingual cultural capital, use transnational media to support highly engaged forms of political participation. For example, "sceptical zappers” are cosmopolitans who seek out and use alternative sources of news and information, display highly flexible modes of reasoning and successfully participate in multiple national and transnational public spaces of communication and socio-political action. Through comparing and contrasting different sources, they construct their own narratives, which may not conform to those put on the agenda by politicians and spin doctors. Instantaneous globally available images, voices and texts (mobile recording devices, blogging) has led to an apparent democratization that blurs the boundaries between such consumers and producers, while the resulting versions of events often challenge national political and media perspectives. But such transnational practices assume high levels of media and political literacy. Among those with low levels of media and political literacy, news avoidance, social insecurity, political alienation and dogmatic modes of reasoning are more common. (Gillespie, 2006). These patterned differences reflect the variability of news and political cultures.

\section{News Cultures: Salience, Credibility and Authority}

Audience ethnography brings together the study of audiences and publics to study the wider news cultures which citizens inhabit. These are culturally specific. In this section I focus on two issues to demonstrate this point: issues of salience, credibility and authority.

News about security issues and policy does not have the same salience for all our interviewees and, of course, its salience shifts in response to critical events and according to one's sense of proximity or distance (geographic and cultural, political and affective) to those events. But our research suggests that it does have very high levels of salience 
Revista da Associação Nacional dos

Programas de Pós-Graduação em Comunicação

\section{(e) compós}

www.compos.org.br

for "racialised minorities" because it implicates them. (The term "racialised minority" is used to emphasise that 'race' is not a useful analytical term that can explain differences. Rather it is a social process - a way of ascribing inferior status to a group on the basis of physical differences - that results in discrimination, segregation and marginalisation). In part, the high salience of security related news reflects the 'state of exception' in which security policy is itself racialised and asylum seekers and refugees are criminalised (Huysmans and Buonfino, 2005).

Two very strong patterns of response are apparent across the interviews that characterise, albeit in general terms, the news cultures of British Muslims and other racialised minority interviewees. First, the British government's apparent "progressive" and "obsessive" attempt to maintain high levels of public fear about the likelihood of a terrorist threat via the media is regarded with cynicism. Second, the tendency of the media to demonise Muslims, to associate Islam with violence, and to refer to "The Muslim Community" as if it were not only a homogenous entity but the "enemy within" triggers deep emotional responses. These range from anger, dismay and sadness to feelings of hopelessness (to effect political change) and powerlessness (to intervene in wider forces at work in the world). These patterns of response combine to reinforce a sense of injury, insult and victimization, not just of British Muslims but of Muslims around the world. Negotiating implicit or explicit accusations of terrorism becomes a daily task and forces people into defensive assertions of Muslim identity.

Our interviewees, in different ways, refer to the pervasiveness, ubiquity and totalising quality of such representations of Muslims and Islam that are seen to trap them in a game of identity politics that they cannot win. For example, Asim, a 29 year old solicitor from Bradford talks of a culture of suspicion and hatred following The London Bombings 07/07/05:

I mean, really, the media have unleashed every bit of hatred they've got within them, every bit of misrepresentation of scaremongering. You can actually feel it now. You can feel the attitudes of people have changed towards you. If you work with nonMuslim people who were really quite indifferent to us at one point - we were just a different colour, a different name, a different set but now I think you're looked at in an evil, suspicious, [..] It's created a culture of suspicion, of hatred. It's something the media seems to be fuelling on an ongoing basis. 
Revista da Associação Nacional dos

Programas de Pós-Graduação em Comunicação

\section{(e) compós}

Whether this is true or not is another question. The fact that it is perceived to be true has consequences. However even those most deeply sceptical about the apparent media and government generated fears, and this includes interviewees of dominant and minority ethnicities, did not entirely dismiss the threat. Whilst discussing the Government's stated reasons for going to war (before 7/7), a group of young working class, English women in their 20s, living in the East End of London explained to the interviewer, Ammar, how they felt about the prospect of a terrorist attack in the UK:

Ammar: When you talk about fear where does it come from, who generates it? Gemma: The media, it has to be.

Kia: Well the Government, they decide what we do need to see and what we don't need to see.

Gemma: Tony Blair swore blind that Saddam has got these weapons that he can just push a button and within two minutes - that's what people were frightened of.

Kia: It's our Government that put about those lies. [Her emphasis]

Ammar: You know when you say 'the media' and 'the government', what, for you, would be the difference?

Aisha: They both run each other so it's hard to differentiate.

Jody: But the media sort of switched half-way through saying they don't have these weapons of mass destruction; they became more open minded.

Aisha: Also, there was the scare because I travel on the Piccadilly Line quite often and there was this scare that Al Qaeda might try to bomb it as it's the Heathrow line, so you have to think 'let's fight them.' [her emphasis]

The women interviewed are conscious of the way that the terrorist threat is being used but they still fear that an attack might occur. Later in the interview they seek to minimise and relativise their fears by relating them to other threats and insecurities (from 'IRA terror threats' and the Madrid bombings to more local fears of unemployment, poverty paedophilia). Deep scepticism about the Government's and the media's manipulation of the threat appear to co-exit alongside fear that an attack might occur 'any time'. But these women respond by refusing to allow it to impinge on their daily lives.

This is a remarkably different response to the way the prospect of a 'terrorist attack' was viewed by a group of 15-16 year old Bengali Muslim girls living in the East end of London. Though they regard the terrorist threat as inflated by media and government, they believe that Usama bin Laden and his followers will inevitably seek revenge for the 
Revista da Associação Nacional dos

Programas de Pós-Graduação em Comunicação

\section{(e) compós}

www.compos.org.br

invasion of Iraq and for the deaths of Muslim mothers and brothers with whom they feel a strong emotional identification. Unlike their older fellow locals, they don't seek to minimise the threat they augment it into an apocalyptic vision. This vision is consistent with a worldview in which powerful forces compete in the world (the US Government, terrorism, fate, Allah). For example, when discussing the news coverage of the Asian Tsunami, the following exchange took place:

Habiba: It's a wake-up call for the world, innit?

Ammar: What d'you mean?

Rumena: Like the end of the world is coming.

Habiba: Like you don't have much time, do you? The wave just showed people that you might just die next day. [her emphasis]

Ammar: So how does that make you feel about life then, when you say it like that?

Habiba: It's coming to an end.

Rumena: There's signs in different ways that I can see it. There's signs. Signs in religious terms and signs in the world terms.

Habiba: The war in Iraq, it's just like the Third World War, innit?

Ammar: So you're saying the war in Iraq is 'a sign'?

Rumena: A lot of people are dying in the world for no reason. [...]

Habiba: Because the world's more advanced, all the things are more...

Rumena: [overlapping] It was probably safer twenty years ago, than it is now.

Habiba: All the ammunition they have now and [...]

Rumena: Crime.

Habiba: If you think about the East End, say for example, where we live, you know. Crime's just increasing so fast.

Ammar: What else makes you think that the world's a scarier place?

Habiba: The war in Iraq.

Ammar: And what else?

Rumena: The Tsunami...

Habiba: Yeah.

Connections are made between the Asian Tsunami, the War in Iraq, the state of the world and crime in the East End. Rumena and Habiba express a sense of fatalistic determination and powerlessness. This apocalyptic vision may be a product of many factors: the interview situation; adolescent fears about the future; living in the East End of London where poverty crime, racism and unemployment are rife; 24-hour rolling news with a constant stream images of violence, war, conflict, death and destruction (see Hoskins in this volume); the interlocking religious discourses of Bush, Blair and Bin Laden (especially the similar Manichean visions of the world split between the forces of 
Revista da Associação Nacional dos

Programas de Pós-Graduação em Comunicação

\section{(e) compós}

www.compos.org.br

good versus evil, “us” versus "them” in which people must decide whether they are with "us" or "them”). While such views and visions cannot be generalised, they indicate how a sense of the proliferation of threats may engender discourses of powerfulness ("there's nothing we can do about it”) and or pragmatism (“we’ve got to get on with our lives”).

The media and government are for the most part seen to work hand in hand and a lack of credibility in both leads to declining authority and which, in turn, leads many to seek out alternative news sources. Most of our multilingual viewers watch or read news in one of their languages (including Islamic channels which alongside BBC are most trusted by some of our British Muslim interviewees) but this is much more common among older first generation migrants than it is among younger and British born people from migrant families (for more details see Gillespie, 2006). Whether people personally consume news in different languages is less important than the fact that other members of their family and social networks do and alternative versions of the news enter in everyday discussions of news. Familiarity with contrasting versions of events engenders a more complex view of plural and competing legitimacies. But it is not only multilingual users of multiple transnational news media that have to negotiate competing and plural criteria and conditions of legitimacy. Monolingual users who consume a very narrow range of news media have to negotiate these too.

We asked interviewees about their sense of security in Britain since the Iraq war. Responses fell into four main patterns. Either they had not become more afraid or insecure; or they did feel more afraid of one of three things: terrorism, racism, or the state (qua surveillance or arrest). Those who have become more afraid of the state are just as numerous as those who have become more afraid of terrorism. As for racism, a high proportion of minority ethnic respondents base their fear on personal experience, or on that of a friend or relative. Others claim indirect knowledge of racism ("heard stories"). The outcome is the same: a diminishing sense of insecurity.

Regardless of ethnicity or religion, socio-economic status or age, most of our interviewees engaged in passionate debate about the rightfulness of the Iraq war 2003 challenging assumptions about the political disaffection and disengagement of the British public. The fundamental concerns of our interviewees were about the legitimacy of the 
Revista da Associação Nacional dos

Programas de Pós-Graduação em Comunicação

\section{(e) compós}

www.compos.org.br

Iraq war, the new direction of UK/USA security policy and its consequences: namely a diminishing sense of security - at personal and local, national and international levels and a sense that the boundaries between these different senses of security are becoming blurred.

\section{Negotiating Legitimacy}

The term legitimacy is only used by a handful of interviewees (those displaying high levels of political and intellectual capital), but the ideological, moral, legal and rational justifications of the war are widely discussed. Naturally, the research design, our questions, and the selection of interviewees afford particular perspectives on these issues. But the sheer disdain with which interviewees - with almost no exceptions - treat the rhetoric of the "War on Terror" (WoT), as an attempt to legitimate security policy, is extraordinary.

Legitimacy is a multivalent and contested political concept. It refers to a quality that inheres in and justifies a power relationship (Gow, 1992: 15)). Legitimacy is the result of processes of legitimation: leaders seek political legitimation via the media, and citizens accept or reject such appeals. Legitimacy is closely related to, but not the same as, the notion of authority. Authority is possessed by a legitimate ruler if he or she is able to gain widespread acceptance of their will, but legitimacy defines why their will is accepted. Establishing and maintaining trust is an important precondition of democratic legitimacy: as trust declines, legitimacy is eroded. ${ }^{4}$ Legitimacy is always a matter of degree. ${ }^{5}$.

Our ethnographic data offers insights which re-balance conventional state-centric notions of legitimacy, in favour of a "bottom up" approach (Merquior, 1980, 6; Gow

\footnotetext{
${ }^{4}$ The relationship between declining trust and legitimacy is evident in polls showing a growing dissatisfaction with Blair, eg: http://www.mori.com/polls/trends/satisf12.shtml. In the Times/ITV News Tracker poll, produced by Populus (April 2005), nearly a half of the public say that they once trusted Mr Blair, but have lost trust in him. Just over a fifth say their loss of trust is because of his handling of Iraq. http://www.timesonline.co.uk/article/0,,19809-1589276,00.html

${ }^{5}$ I draw here on Beetham's approach (1991), which highlights the variable conditions which contribute positively or negatively to legitimation. Refusal or withdrawal of consent involves actions ranging from passive resistance and non co-operation to open opposition and militant disobedience.
} 
Revista da Associação Nacional dos

Programas de Pós-Graduação em Comunicação

\section{(e) compós}

www.compos.org.br

1992, 16). ${ }^{6}$ This approach enables us to engage with the evaluative, moral content of legitimacy and affords some political agency to news publics and their discursive activities. It is in media and in talk about media that the struggle over legitimacy is largely conducted. Ethnographic analyses of media talk about security can reveal the differential discursive logics of legitimation. However, they are not generalisable, nor do they reflect any essential truth. Media talk is always contextual. The individual or group interview situation, and the power relations embedded in it, powerfully affect meaning making. Our data underscores the relational, provisional, inter-subjective dimensions of ongoing processes of legitimation and delegitimation via engagements between government, media and diverse publics.

Our data suggests that a serious "legitimacy deficit" has been unleashed by the decision to go to war in Iraq (Beetham, 1991: 20). A democratically forged security policy should be founded on active participatory citizenship, informed debate and a good measure of public consent. This can only be achieved if is there is a common public, political and moral language to discuss competing claims and contested legitimacies. Government has a duty and a responsibility to persuade the public of the rightfulness of its decision making, especially when the issue concerns not just domestic politics but war.

Weber's tripartite typology of bases for legitimacy - tradition, law or reason, and charisma - provides a useful starting point for an assessment of how our interviewees debate the legitimacy of UK security policy (Weber, 1968: 215-6). Although I did not set out to use this framing, I found that our interviewees' judgements can broadly be mapped in accordance with this typology, although the three bases overlap. ${ }^{7}$

\footnotetext{
${ }^{6}$ Weber sought a value-free way of analysing the problem of "legitimate domination", to avoid the risks of the moral and or ideological judgements of the analyst taking precedence. Weber's conceptualisation of legitimacy has been subject to many criticisms: not least that it is rulercentric, or that it focuses on the legitimations sought by rulers at the expense of the "view from below".

${ }^{7}$ Beetham criticises Weber for, among other things, reducing legitimacy from a complex of factors which encourage compliance, to a single dimension: namely the idea that power is legitimate because people believe it to be so. However, Weber's theory need not have the reductionist or manipulative implications that Beetham identifies.
} 
The traditional basis is founded on a belief in the sanctity of tried and tested traditions. Public consent is granted to decisions and policies made by those in possession of traditional authority. Tradition also connotes custom and convention which shape the parameters and expectations of how leaders should act. As we shall see, when a leader acts in an unexpected or surprising way, be it in defiance of convention or custom, or in defiance of previously agreed policy, consent (formal or informal, tacit or tangible) may be withheld. This not only undermines the ruler's legitimacy. It may undermine the legitimacy of the political system.

The legal/rational basis is founded on a belief in the legality of agreed rules, and in the right of those in authority to make rules and issue orders. This ensures compliance with decisions made by those occupying positions of authority, and acceptance of the public prestige conferred both on that position and on those persons. Today, "rules of engagement” are negotiated and if possible agreed at national and international levels. Conflicts over their legal status and interpretation are frequent.

The charismatic basis refers to a belief in the exceptional, exemplary personal characteristics of leaders. Today the personalisation of politics and celebritization of politicians works both to affirm and to undermine the extraordinary qualities of leaders. Media exposure brings them “up close and personal”, but from a distance. Paradoxically, leaders are both ordinary and extraordinary, accessible and remote. What we might call "banal charisma”, or the ability to impress and influence, becomes in large part a function of media "spin".

\section{Tradition}

Responses evaluating the invasion of Iraq in terms of tradition highlight both ruptures and continuities with time honoured conventions. For sceptics, Bush and Blair's justification of the war as the next stage in the WoT seemed incredible. But sceptics fall into two camps: those whose expectations were disrupted, and those who were not in the least surprised

Sonya, a teenage British Bengali Londoner, was puzzled: 
Revista da Associação Nacional dos

Programas de Pós-Graduação em Comunicação

\section{(e) compós}

www.compos.org.br

Can I ask you something right? You know with Christianity, it was meant to be that they have to go to war with a certain reason. They just don't go to war. But Bush didn't go to war according to a Christian way of going to a war

Sonya's appeal to a Christian religious framework, from a Muslim perspective, like many other interviewees, implicitly invokes "Just War" traditions and the "principle of necessity”. Her statement underscores the importance of a common moral basis and language, across religious diversity, for having a meaningful public debate about military action. She is far from alone in perceiving an alarming discontinuity with established political and religious conventions. ${ }^{8}$ There were those who gave Blair the benefit of the doubt. However, as became evident in subsequent interviews, they soon changed their minds. A common refrain is captured by a white, working class driver in his 50s, from Milton Keynes:

Tony Blair said “Trust me” so I did. But then he lied. Now I can’t believe a word he says

Shahed, Sonya's class-mate, was bemused by an abrupt and apparently illogical shift in policy:

What I don't understand is four years after 9/11 that's what happened. The year after 9/11, all this time, [...] he was really focused on Bin Laden, how to get him. Suddenly he's gone toward Saddam Hussein. George Bush goes towards Saddam Hussein. That's what I really don't understand

For some, especially older interviewees, the war came as no surprise at all. Here Shelagh, 82, from Belfast describes how she felt at the time:

I remember before they went in thinking, these people are going in here gung-ho, but they're gonna have great difficulty coming out of it again [...], and I had [..] seen a documentary about America's role as a police man, and this guy, McNamara [secretary of Defence in the Kennedy and Johnson adminstrations from 1960-68...] reflected on the twentieth century, and that America should never do anything unilaterally. But it would

\footnotetext{
${ }^{8}$ The quotes from interviews - like the interviewees - were not selected for "representative" value or statistical generalisability. Qualitative social interviewing aims instead to elicit indicative, typical, but also revealingly unusual responses, and so to identify patterns in modes of reasoning and affect.
} 
Revista da Associação Nacional dos

Programas de Pós-Graduação em Comunicação

\section{(e) compós}

www.compos.org.br

appear that the administration who went in to Iraq weren't listening, or weren't aware of history, American military history, to the extent that he was

The fact that Bush and Blair appeared ignorant of historical precedents was often remarked upon. Many interviewees draw on such precedents to judge the legitimacy of the Iraq war. John, a white working class builder in his 60s, a Labour voter all his life until the war, spoke passionately:

America, they've got the finest planes, the ships, the troops, they've got helicopters and every ammunition you can think, and it's no different today than it was hundreds of years ago when they were fighting Indians with bows and arrows! They had guns! And that's what they're doing out there. It's no different. Once they've got power they want to use it. [...] What do we want to attack them for? I mean we're ready if someone attacks us but [...] War against terror! (laughs ironically) Let me tell you we'll always have terror! Don't matter what you do, so far as the Americans are concerned, there'll always be nuclear war threats, you'll always have terror [...] because they're threatening it [...] yeah they threaten it. They've taken control of the earth! Almost like the Romans say [...]

Similarly, for Jay, 60, a London Indian, the war in Iraq followed squarely in the tradition of American imperialism. Like many informants, he displays deep disdain at what he sees as Anglo-American arrogance in believing that western models of democracy and human rights can be "exported":

I think there were better ways of handling this - you don't go to war! The West's complete preoccupation is with democracy and things like this being a solution for everything - this doesn't apply in some countries. And they seem to assume democracy equals... that human rights will come in and bring equality but this won't be.

In making sense of the war in Iraq, our interviewees appeal to political and religious traditions, and historical precedents. They refer to traditions, conventions, and corresponding expectations. Their interpretative processes are mediated by personal and political histories as well as by the news cultures they inhabit.

\section{Legal and Rational Bases of Legitimacy}

Tradition and custom dictate the powers exercised by the Prime Minister. But to be legitimate, these powers must be exercised on a legal and rational basis. The sources 
Revista da Associação Nacional dos

Programas de Pós-Graduação em Comunicação

\section{(e) compós}

www.compos.org.br

of laws and rules are now multiple. International institutions can claim precedence over nation states. In this section I examine responses to attempts to justify the invasion of Iraq on legal grounds and then consider how the WoT more generally is widely seen to have instigated, a "state of exception" (Agamben, 2005) in which civil liberties are being threatened. At the time of going to war, the justifications proffered by Bush and Blair were seen as forceful enough to override the lack of UN backing. Russell, a Swansea newsagent in his 50s, explains how his views changed:

Right well, the well publicised reason was the weapons of mass destruction matter, and the business of the 45 minutes. I seem to remember them launching it and then forgetting it as it were, err. I suppose that it was sort of accompanied by reports of ethnic cleansing of the Kurds in the North [...] then having gone to the UN to sort of ask their permission and not getting it and then in the end, however, the Americans went in didn't they and, at the time, you were swept away with it - it was all about good against evil [...] perhaps I was naïve [...] I thought it was going to be a quick sort of thing [..] innocent people wouldn't get hurt [...] we were going to be the saviours [...] Saddam Hussein needed to be got rid of [..] but they were economical with the verité, you might say (laughing ironically)

The failure to get UN backing rang warning bells for some. Harry, also from Swansea, a retired lecturer, believes that Tony Blair "fell into a trap" that he had set for himself:

Once one admits that you need the validating power of the UN and seeks it, one has a problem when it doesn't give it, and then you say, "it would have been nice to have it but it wasn't really necessary”, that's the trap that Blair fell into.

Thorsten, a Cardiff teacher in his 50s, uses metaphorical language and clichés- a characteristic popular political discourse:

I believe that it was illegal, it was all done through a system of smoke and mirrors, because they [Bush and Blair] were harking back to a series of UN resolutions which really didn't have any relevance to the things they were pointing to, and the rest, you could say, was "lies, damned lies and statistics": the supposed chemical weapons; the supposed nuclear weapons - all somehow disappeared. They ran rough shod over Hans Blix, over his wanting to finish looking for what they said was there, and they built up a picture of misinformation - interestingly, Bush leaning on evidence gleaned amazingly from the British, and the British leaning marvellously on what was said that was reflected in those smoking mirrors from the USA. So, no, the war 
Revista da Associação Nacional dos

Programas de Pós-Graduação em Comunicação

\section{(e) compós}

was not legal! There was no imminent threat! [...] I discount systematically a good percentage of what politicians say, like good journalists do actually

Very few interviewees commented in such detail on the legality of the war. Some were at a complete loss to understand why the invasion of Iraq took place at all. But John, the builder from Swansea, shows knowledge of the situation:

Saddam Hussein, he complied with the UN 1441 resolution [...] He was no threat to us! No threat at all [...] If he hadn't let the UN in then you could see a clear reason $[\ldots]$

Thorsten also comments on the domestic legal controversy: the Attorney General (Lord Goldsmith) “never gave a straight answer” and changed his mind about the legality of the war after "being lent on”. Criticism of an occupant of a position can lead to criticism of the position, and of legal and political institutions themselves. Some of our more politically involved interviewees judge that Tony Blair's extensive use of the powers available to him, through the Royal Prerogative, cast doubt on the validity of British political institutions. Unlike many other national leaders, the British Prime Minister can declare war (among myriad other powers) without consulting parliament. Blair did not need to seek parliamentary ratification of the invasion of Iraq, but he did so, only winning by a slim majority. Warren, a retired solicitor and former Labour activist in his 60s, put it like this:

Why was it possible to go to war and why was it possible to gain a majority in the House of Commons? Because their livelihoods depended on it - they couldn’t afford to go against it [...] most professional politicians are completely ineffective as protestors against powerful executives. High concentrations of power and a profound collapse of the checks and balances system, that's why we went to war! [...] These institutions are atrophying and are losing respect almost by the minute, but the question is: how do you build new institutions that will command respect?

Such politically well-informed interviewees are able to mount very plausible arguments as to why security policy has thrown into question: not just the legitimacy of the leader, and that of the occupants of key positions in the executive and judiciary, but the very institutions that constitute the political system. 
Revista da Associação Nacional dos

Programas de Pós-Graduação em Comunicação

\section{(e) compós}

Many interviewees raise concerns about the way in which regular use of “emergency powers", justified in the name of the WoT, are eroding civil liberties and the democratic fabric of society. Some of the more politically engaged see a very serious threat here, Harry, the retired lecturer, said:

The new laws of detention go against the very custom and tradition of British politics. But PM Tony Blair is a revolutionary - he is against custom and tradition. He hates it. He jeers at it. Take the way the abolished the post of the Lord Chancellor - the chief law officer of the land - gleefully sweeping it away without any consultation with Cabinet. This was an act befitting a dictator. If we had a written constitution this would not happen.

Harry advocates constitutional reform: the abolition of the monarchy, a head of state with ceremonial and symbolic functions, and a written constitution which devolves all powers to parliament. Warren goes further: representative democracy is in crisis, and he advocates participatory democracy:

The government are aware that their legitimacy is generally declining, simply because the systems are too big in this country [...] In this country, we are trying to run a centralised system for 60 million people (laughs) and all decisions about security are taken with a view to maintaining the power of central government and the government have, as it were, found a new product, particularly since $9 / 11$, and that new product is offering the electorate security, protection against terrorism. Now that's a false prospectus because it's clear that you cannot do this - but they are desperate to make promises, to make offers to the electorate which are attractive [...] I yearn for a system of participatory democracy not least because its more fun!

Like most of our interviewees, Warren understands very well that the government faces new security challenges. Terrorism is not to be dismissed. But he advocates devolved solutions, such as more community police officers: people who "know their patch”, and can recognise what is unusual or threatening. Devolving power to cities and regions, even neighbourhood government (along the lines of the French communes) might slowly re-establish diminishing trust, credibility and legitimacy, he argues. This is a task, he feels, is as important as tackling terrorism and security.

The delegitimation of political institutions is less of an issue for other interviewees, who experience the effects of anti terrorist legislation in everyday life: 
Revista da Associação Nacional dos

Programas de Pós-Graduação em Comunicação

\section{(e) compós}

www.compos.org.br

racialised minority ethnic groups. Luke, a Muslim convert from Edinburgh, puts it succinctly:

British Muslims actually believe that because of the new terror laws that anybody can get arrested now and it's true it really is.

These laws are very widely criticised by our interviewees. Nawaz, a Scottish Pakistani in his 40s:

[...] They have plenty laws to deal, you see, with any criminal type of people and any situation. And the new kind of laws, like the shoot to kill, these things, again will create a high handed state [...] If you use these laws that will create a lot of constraint of opinion, expressing opinion, like what happened in Brighton last days, (laughs) an 82 year old person was thrown out of, you see, conference hall. [...] Certainly if you give your opinion against these laws, these things, it doesn't mean you are supporting terrorists. But you can use these laws against your enemies, against your political enemies

Luke [age etc] knows a man who was arrested under anti-terrorism legislation as a bomb-maker, when he was in fact manufacturing Arabic sweets:

I mean how do you think that, I mean it's just awful, it's just, I mean, what's the difference between us and Syria or Iraq, that we, or any other Middle-Eastern dictatorship? Especially the way that a lot of people have been actually sent to Egypt [...] a British Pakistani guy who had been sent, been flown by American agents to Egypt to be tortured to get more information out of them. What the hell is that all about? They say that they want democracy then they go and use the secret police force - so what's the difference?

Judgements of legitimacy are often based on comparing and contrasting political situations. Anti-terrorist legislation is but one source of concern about the uses and abuses of law. There are hundreds more instances across the interviews where other kinds of breaches in law are discussed with at least equal depth of feeling. Breaches of the rules or laws of war - in particular, civilian deaths and the abuse or torture of prisoners - are seen to play into the hands of terrorists by undermining the moral and political legitimacy of the UK. So too are anti-terrorism laws which may be abused, and which curtail public rights of protest and debate. A very widespread view is that such legislation cannot but fail, and that the root causes of terrorism must be tackled: these being most often cited as the Israeli-Palestinian conflict, and the perceived Western "war on Islam”. 
Revista da Associação Nacional dos

Programas de Pós-Graduação em Comunicação

\section{(e) compós}

www.compos.org.br

There is a widespread view that the UK public are politically supine or disaffected. In general, however, we found strong affective responses to security policy questions, coupled with critical political engagement and rational argument.

\section{Charisma}

Few political leaders today possess full-blown, Weberian, “sanctifying” charisma. But a leader's exceptional or exemplary qualities still form a basis of the judgment of their legitimate rule. Tony Blair is often said to have a certain charisma. Russell, the newsagent, claimed:

You may not agree with him but you certainly sit up and listen when he talks [...] Even though his policies have been criticised, and much as I now question what he's done, he's probably still the best politician we've got. Who's the alternative?”

But the same qualities of self-presentation and personal authority may be viewed in different lights. John, the builder, compares Tony Blair to Saddam Hussein:

\footnotetext{
He's a great man, see, loved by some Iraqis, he was a great man to thousands of them. It's just like, you know, Tony Blair, a lot of people hate him, a lot of people like him [...] I didn’t like him [...] I don’t trust him [...] I don't believe what he says! [...] Do we really believe they [British troops] are dying for a good cause?! For Iraqis?! I mean he's conned us, it's wrong, and they're still out there and there'll be many hundreds more killed before he's finished! [...] It's going to be a long and bitter war!
}

Comparisons between the charisma of Saddam, or Osama bin Laden, and that of Blair and Bush, are common. Leading political actors are mainly discussed in a highly personalised way, reflecting how events are understood through personalities. Here Malik, a young British Bengali Muslim in his late teens in Tower Hamlets, conflates Bush and the Coalition:

I think Bush is, like, in general trying to destabilize the Islamic countries. There is a specific war for whatever reason Bush and Blair might have on their mind. 
Revista da Associação Nacional dos

Programas de Pós-Graduação em Comunicação

\section{(e) compós}

www.compos.org.br

Others personalise politicians in satirical, defamatory, mocking tones. Here a group of Scottish-Pakistani in their 40s discuss the notorious "45 minute" claim:

Babil: Even the newspapers then didn't believe him but they went along with it Jamil: Yeah they could launch an attack on Britain or somewhere. They know exactly how far those Scud missiles can go. You know, Scud missiles, only 50 to 150 miles $[\ldots]$

Babil: They've got every satellite pointing at Iraq who have no satellites in the air Nawaz: And his targeting is pretty poor as well (laughter)

Shabir: And poor Cheri is getting worried: "come on Tony we need to get into a bunker" or something (laughter) He'd say: "don't worry, it's a load of rubbish (Everyone: laughter) just to fool that lot” (laughter)

The inaccuracy about weapons and the comic tenor of this exchange, no doubt inspired by political satire, do not detract from the critical point of the humour: that the media collude with lying politicians in order to deceive the public. One particular personalizing analogy occurs in several interviews. Far from Weber's charismatic prophets, our leaders are more like children in a playground. As Kashif, a 44 year old computer software engineer from Surrey, put it:

They are normal people, they just happen to be those in power and with authority. [...] It became like playground politics. Acting like bullies, trying to isolate people they didn't want to influence the rest of the playground. And they wanted to get the best part of the playground for themselves.

Deprived of charismatic and other legitimacy, leaders are equated. Jamil and Shabir, two Scottish Pakistani businessmen:

Jamil: Was there difference between Saddam Hussein and Blair, no there wasn't. One used "mother of all battles" and the other used "weapons of mass destruction". [...] Shabir: That's what I'm trying to say, they both, er, all politicians (laugh) I mean, will mislead people.

Babil: But I did not expect that of Blair not to that level. Okay, to a small manipulation, but to the wholesale use of words like "weapons of mass destruction”...

Many of our interviewees confirm trends in opinion polls. After the Iraq invasion, and particularly after the "dodgy dossier" on weapons of mass destruction, Tony Blair is progressively losing trust, and credibility (See Note 3). Whatever charismatic authority 
Revista da Associação Nacional dos

Programas de Pós-Graduação em Comunicação

\section{(e) compós}

www.compos.org.br

he may have had at the outset of the war has been severely diminished. The personalisation of politics reduces the war in Iraq, and the WoT, to a battle between individuals, into which soldiers - and civilians - are dragged.

\section{Conclusions: Transnational Media and Plural Legitimacies}

Our research findings testify to a growing disjuncture between government, media and publics since the invasion of Iraq: a progressively widening and corrosive gap which challenges not only the legitimacy of Blair's administration, but even appears to question British democratic institutions and practices. But legitimacy is always a matter of degree. This has not produced a full blown crisis of legitimacy - the public have not demanded a new political system - despite pervasive feelings of powerlessness and alienation, anger and even despair among some of our interviewees. But it is has resulted in a substantial legitimacy deficit which has significant negative implications for participatory democracy and multicultural citizenship.

Weber's schema has served a useful purpose. It has been possible to analyse judgements about the legitimacy of security policy decisions on the grounds of tradition and convention. Some interviewees emphasise the sudden rupture from conventional ways of justifying war: notably the shift from defensive military action in response to an external threat, to pre-emptive or preventative action. Others see the invasion of Iraq as entirely consistent with American militaristic imperialism. Even those who supported the war beforehand, or expressed some understanding of the Coalition's aims, feel that the war cannot be legitimated by appeals to traditions of the "Just war" or Christian ethics. Nor could the war be legitimated on legal/rational grounds, according to those interviewees who were able to discuss these in any detail of depth. Different legal arguments clashed (UN, UK, USA) and the rationality of the war was disputed. Similarly our interviewees could not confer legitimacy based on charismatic leadership. Whatever charismatic authority PM Tony Blair and President W B Bush might have had, is progressively diminishing. If at least two of these bases must be right to confer legitimacy on security policy and, as consequence, a favourable sense of "security" then 
Revista da Associação Nacional dos

Programas de Pós-Graduação em Comunicação

\section{(e) compós}

www.compos.org.br

Weber's schema, if not exactly original, helps us explain our interviewees diminished sense of security.

In almost homologous fashion, as the legitimacy of political leadership declines so, too, does the authority of the news media tends to wane. The news media and politicians, regardless of their differences, divisions and battles, are seen to work hand in hand, albeit in agonistic fashion. At a general, societal level, a majority of our interviewees subscribe to a "manufacture of consent" thesis about the relationship between media and politics. Racialised minorities are particularly critical of both USA/UK foreign policy and of 'western news media' for their collusion with politicians, their ethnocentric bias and Islamophobic tendencies. Yet paradoxically, dissatisfaction with news does not discourage its consumption. Rather it tends to encourage people to seek out and test alternative sources of news. Familiarity with contrasting versions of events, via transnational media and the internet, can engender a more complex view of competing and plural legitimacies and contribute to cosmopolitan and multicultural practices and forms of citizenship. Conversely, low political and media literacy contribute to feelings of political alienation, powerlessness and dogmatic modes of reasoning.

Our data underscores the relational, provisional, inter-subjective dimensions of processes of positive and negative legitimation in the spaces of communications forged between government, media and multi-ethnic publics. Audience ethnography provides fine-grained, close-up pictures of these processes at work, testing and challenging assumptions of epochal change in international relations, pointing instead to the slow erosion of civil liberties and the emerging threat posed by increasing cultural, political and economic polarisation.

It is in media and in talk about media that struggles over legitimacy are largely conducted. Ethnographic analyses of media talk about security policy can reveal the differential discursive logics expounded by leaders and publics and point to failures in communication. But legitimacy is much more than a product of political spin or successful public relations. And it has to be founded on more than the beliefs of citizens. Even if is easier to document its absence rather than its elusive presence, objective 
Revista da Associação Nacional dos

Programas de Pós-Graduação em Comunicação

\section{(e) compós}

www.compos.org.br

analyses of the legitimacy of political systems alongside this kind of more subjective ethnographic analysis, is vital if academic analysis is to contribute to democratization.

This article highlights the need for a common political and moral language to facilitate a more inclusive democratic debate about shifts in security policy and plural legitimacies. But the perceived authoritarianism and centralisation of power by PM Tony Blair is a source of growing social unease - even among our most politically apathetic interviewees. So, too, is the growth of surveillance technologies and the creeping militarisation of British society. These are widely seen as the product of a security policy forged on a politics of fear that is an American ideological export. At the same time, there is widespread recognition of the need to tackle terrorism.

Expanding the definitional boundaries of the term "security" in order to legitimate the WoT has blurred many social categories and distinctions (minorities, migrants, refugees, asylum seekers, terrorists, criminals) and is exacerbating racism and racialisation - conflating threats from inside and outside and creating "enemies within". The seemingly limitless polysemy of the term security is reducing its analytical usefulness while, for many of our interviewees, its connotations with militarism, terrorism and insecurity are crystallising.

A diminishing sense of security among our interviewees - at personal and local, national and international levels - is often accompanied by a feeling that the boundaries between these different senses of threat (from inside and outside national boundaries) and security (international, national and personal) are becoming increasingly blurred. The “state of exception" brings national security policy into everyday life as a threat to personal security. Harry, the retired lecturer from Swansea, speaks of living in a state of continual and increasing uncertainty, of "a thousand pin pricks of insecurity" in daily life, as long-standing, taken for granted assumptions are continuously challenged. For racialised minorities living in metropolitan centres, the consequences of security policies have more far reaching and unpredictable consequences. We should be mindful of the potentially damaging consequences of security policy if our chances of living in a peaceful multicultural state are not further to be diminished. 
Revista da Associação Nacional dos

Programas de Pós-Graduação em Comunicação

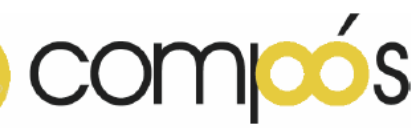

www.compos.org.br

\section{Bibliography:}

Agamben, G. (trans. K. Attell), State of Exception Chicago: University of Chicago Press, 2005.

Aksoy, Asu. "Transnational Virtues and Cool Loyalties: Responses of Turkish-Speaking Migrants in London to September 11'? Journal of Ethnic and Migration Studies, July 2006.

Beetham, David. The Legitimation of Power: Issues in Political Theory London: Macmillan, 1991.

Gillespie, Marie (ed). Media Audiences Maidenhead: Open University Press and The Open University, 2005.

Gillespie, Marie. “Transnational Television Audiences after September 11 2001” in Special Issue: Television News and Transnational Publics after September 11 2001, Journal of Ethnic and Migration Studies, 2006.

Gow, James. Legitimacy and the Military: The Yugoslav Crisis London: Pinter Publishers, 1992.

Huysmans, Jef and Buonfino, Alessandra. "Politics of Exception \& Unease: Immigration, Asylum and Insecurity in Parliamentary Debates on Terrorism in the UK". Paper presented at Annual Conference of the British International Studies Association, University of St Andrews, 21-23 December, 2005.

Livingstone, Sonia. Audiences and Publics: When Cultural Engagements matter for the Public Sphere Bristol UK \& Portland, OR: Intellect, 2005.

Merquior, J.G. Rousseau and Weber, London: Routledge and Keagan Paul, 1980.

Rajagopal, Arvind. Politics After Television: Hindu Nationalism and the re-shaping of the Indian Public Cambridge: Cambridge University Press, 2001.

Weber, Max. Economy and Society California: University of California Press, 1968. 